\title{
KAJIAN ASPEK TEKNIS KAPASITAS TAMPUNG SISTEM DRAINASE PERUMAHAN TLOGOSARI KOTA SEMARANG
}

\author{
Bambang Tutuko ${ }^{1^{*}}$, Diah Setyati Budiningrum ${ }^{2}$ \\ 1,2 Jurusan Teknik Sipil Fakultas Teknik Universitas Semarang \\ Jl. Soekarno Hatta, Tlogosari , Semarang, Jawa Tengah, Indonesia \\ *e-mail : bamtutuko@usm.ac.id
}

\begin{abstract}
The Tlogosari Housting in Semarang City always floods every rainy season, therefore it is necessary to review the drainage system in this area. The most important criteria in the drainage system are technical aspects, in addition to non-technical and environmental aspects. The research objective is to assess the performance of the drainage system by calculating the existing capacity of the drainage channel and assess the performance of a sustainable drainage system based on community perceptions in Tlogosari Housing Semarang. The method is by comparing the existing capacity of the drainage channel with the planned flood discharge. The result is that the capacity of the Tlogosari River is smaller than the planned discharge. However, with a high level of guarding, where the capacity of the reservoir is greater than the planned discharge, the Tlogosari River should not overflow during the rainy season. The overflow of the Tlogosari River is due to the large amount of garbage and thick sediment and the not yet normalized Tenggang River as its primary channel which causes Tlogosari to always flood during the rainy season. In the secondary channel some of the capacity is smaller than the planned discharge. The recommendation is that the dimensions of the secondary channels need to be enlarged. So the performance of the drainage system in Tlogosari Housing based on its storage capacity is sufficient and poor in its secondaries channel.
\end{abstract}

Keywords: drainage system; performance; capacit; , technical

\begin{abstract}
ABSTRAK
Perumahan Tlogosari Kota Semarang selalu banjir setiap musim hujan, oleh karenanya perlu dikaji kembali system drainase di wilayah ini.. Kriteria terpenting dalam sistem drainase adalah aspek teknis, selain aspek non teknis dan lingkungan. Tujuan penelitian adalah menilai kinerja sistem drainase dengan menghitung kapasitas tampung eksisting saluran drainase dan menilai kinerja sistem drainase yang berkelanjutan berdasarkan persepsi masyarakat di Perumahan Tlogosari Semarang. Metodenya dengan membandingkan kapasitas tampung eksisting saluran drainase dengan debit banjir rencana. Hasil yang diperoleh adalah kapasitas tampung Sungai Tlogosari lebih kecil dari debit rencananya. Namun dengan adanya tinggi jagaan, dimana kapasitas tampung menjadi lebih besar dari debit rencananya, seharusnya Sungai Tlogosari tidak meluap saat musim hujan. Meluapnya Sungai Tlogosari adalah karena banyaknya sampah dan tebalnya sedimen serta belum dinormalisasinya Kali Tenggang sebagai saluran primernya yang menyebabkan Tlogosari selalu banjir jika musim hujan. Pada saluran sekunder sebagian kapasitas tampung nya lebih kecil dari debit rencananya. Rekomendasinya adalah dimensi saluran-saluran sekunder perlu diperbesar. Maka kinerja sistem drainase di Perumahan Tlogosari berdasarkan kapasitas tampung eksistingnya adalah cukup pada saluran sekunder dan buruk pada saluran tersiernya.
\end{abstract}

Kata kunci: sistem drainase; kinerja; kapasitas tampung; teknis 


\section{PENDAHULUAN}

Perumahan Tlogosari Kota Semarang merupakan salah satu lokasi strategis di Kota Semarang. Selain dekat dengan pusat kota, fasilitas umumnya juga lengkap seperti pertokoan, perkantoran, pendidikan dan hiburan. Sebagaimana mana wilayah Kota Semarang daerah utara, banjir adalah masalah yang selalu terjadi setiap musim hujan, akibat luapan Sungai Tlogosari yang tidak mampu menahan debit air sehingga meluap sampai ke jalanan. Danianti dan Sariffuddin (2015), meneliti tentang tingkat kerentanan masyarakat terhadap bencana banjir di Perumnas Tlogosari Kota Semarang untuk mengetahui tindakan adaptasi yang tepat, dengan hasil bahwa banjir yang terjadi membawa dampak yang merugikan bagi masyarakat baik dampak fisik, sosial, ekonomi maupun lingkungan. Namun masyarakat Perumahan Tlogosari adalah masyarakat yang berketahanan dalam menghadapi banjir.

Banjir di suatu kawasan berkaitan dengan sistem drainase dimana sistem jaringan drainase di suatu kawasan dirancang untuk menampung debit aliran yang normal, terutama pada saat musim hujan. Saluran drainase diperhitungkan kapasitasnya untuk dapat menampung debit air yang terjadi sehingga kawasan yang dimaksud tidak mengalami genangan atau banjir. Jika kapasitas sistem saluran drainase menurun dikarenakan oleh berbagai sebab maka debit yang normal sekalipun tidak akan bisa ditampung oleh sistem yang ada. Sebab menurunnya kapasitas sistem antara lain, banyak terdapat endapan, terjadi kerusakan fisik sistem jaringan, atau adanya bangunan lain di atas sistem jaringan. Penyebab meningkatnya debit antara lain, curah hujan yang tinggi di luar kebiasaan, perubahan tata guna lahan, kerusakan lingkungan pada Daerah Aliran Sungai (DAS) di suatu kawasan.

Beberapa penelitian yang berkaitan dengan kinerja sistem drainase telah dilakukan sebelumnya. Kinerja sistem drainase dipengaruhi oleh faktor operasi pemeliharaan, pengelolaan dan teknis sebagaimana telah dilakukan penelitian oleh Suryanti dkk (2013) yang menganalisis tingkat pengaruh faktor operasi pemeliharaan, pengelolaan dan teknis terhadap kinerja sistem jaringan drainase Kota Semarapura di Kabupaten Klungkung. Hasil penelitian menunjukkan bahwa operasi pemeliharaan lebih dominan berpengaruh terhadap kinerja sistem jaringan drainase dibandingkan dengan faktor pengelolaan dan faktor teknis. Upaya yang dilakukan untuk peningkatan kinerja sistem jaringan drainase Kota Semarapura adalah dengan menyusun sistem operasi pemeliharaan yang terstruktur sehingga operasi pemeliharaan dilakukan secara teratur, membentuk kelembagaan pengelolaan drainase sehingga wewenang dan tanggung jawab dapat dikoordinasikan secara terarah serta membuat peraturan sistem pengelolaan yang jelas, melakukan perbaikan kerusakan infrastruktur drainase sesuai dengan persyaratan teknis.

Sungai Tlogosari perlu diteliti sejauh mana kemampuannya melayani kebutuhan drainase Perumahan Tlogosari. , dan agar dengannya dapat diadakan studi bagaimana mencegah terjadinya banjir di kawasan ini sehingga wilayah Perumahan Tlogosari tetap menjadi lokasi yang memenuhi syarat sebagai tempat tinggal yang nyaman. ini menitik beratkan pada kinerja saluran drainase Sungai Tlogosari. Kinerja drainase dapat diukur dari kapasitas tampungnya dengan tinjauan aspek teknis, non teknis dan lingkungan. Tujuan penelitian ini adalah menganalisis kinerja kapasitas tampung Sungai Tlogosari dari aspek teknis.

\section{METODE PENELITIAN}

Pengumpulan data dilakukan dengan dua cara, yaitu survei lapangan dan survei pustaka / dokumenter. Survei lapangan digunakan untuk memperoleh data primer yang berupa dimensi dan kondisi saluran drainase meliputi panjang saluran, jenis saluran, dimensi saluran, sedimentasi, sampah kemudian dibandingkan dengan standar acuan yang ada. Survei pustaka digunakan untuk memperoleh data-data sekunder, yaitu data hidrologi 
kawasan, demografi dan geografi Perumahan Tlogosari, undang-undang dan peraturan tentang bangunan sarana dan prasarana drainase. Metode penelitian dapat dilihat pada Gambar 1.

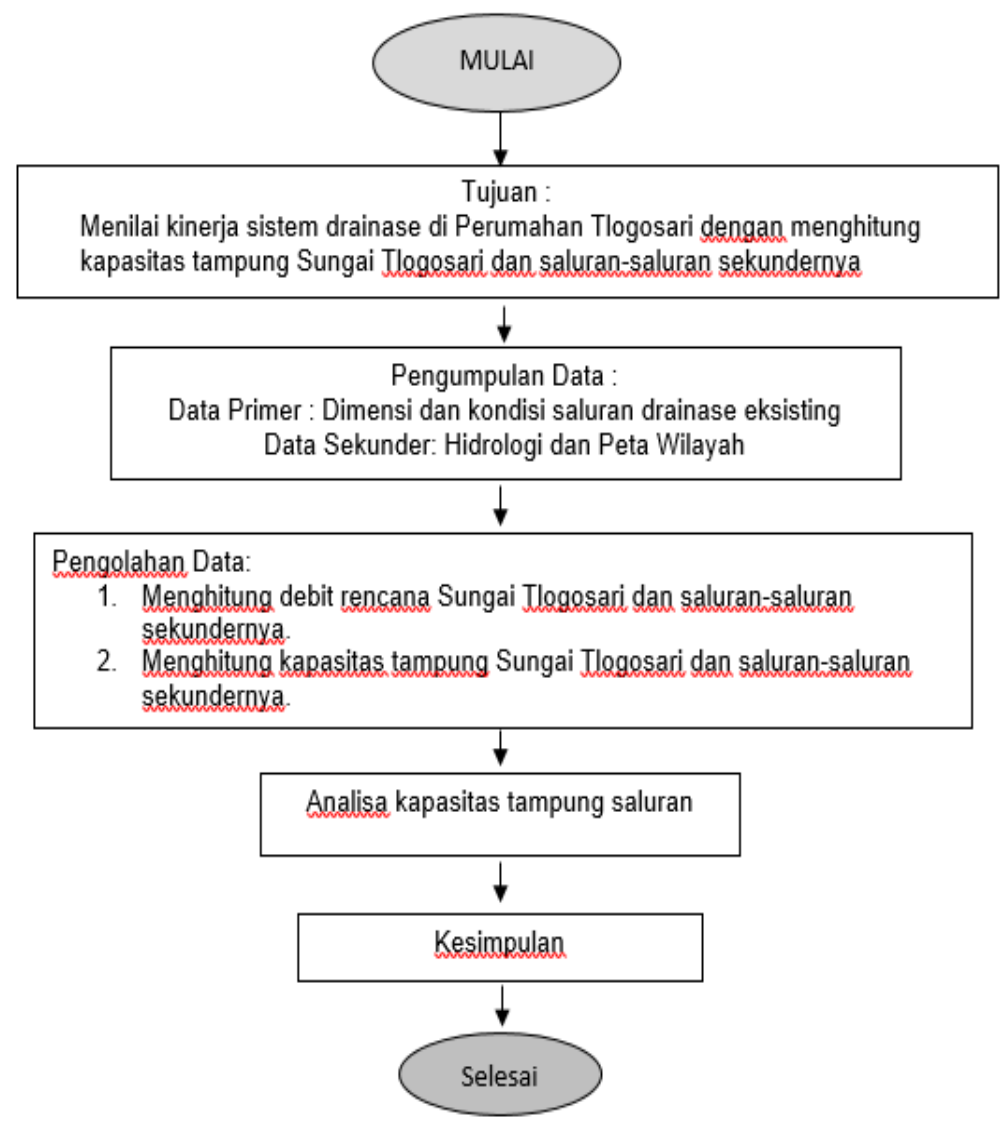

Gambar 1. Bagan Alir Penelitian Sumber: Peneliti, 2018

HASIL DAN PEMBAHASAN

Analisis Debit Rencana

Analisis ini menggambarkan kondisi sistem drainase berdasarkan kapasitas tampungnya, yaitu menghitung kapasitas tampung Sungai Tlogosari dan saluran sekundernya. Kapasitas tampung saluran didasarkan pada perhitungan debit banjir rencana. Perhitungan debit banjir rencana menggunakan data hujan dari stasiun curah hujan terdekat yaitu Stasiun Curah Hujan Karangroto, mulai tahun 2005 sampai tahun 2015. Dari data hujan dihasilkan curah hujan maksimum setiap tahun ditunjukkan pada Tabel 1.

Tabel 1. Curah Hujan Harian Maksimum Rata-Rata Stasiun Karangroto Th. 2005 - 2015

\begin{tabular}{cccccccccccc}
\hline No & 1 & 2 & 3 & 4 & 5 & 6 & 7 & 8 & 9 & 10 & 11 \\
\hline Tahun & 2005 & 2006 & 2007 & 2008 & 2009 & 2010 & 2011 & 2012 & 2013 & 2014 & 2015 \\
\hline $\begin{array}{c}\text { Rmaks } \\
(\mathrm{mm})\end{array}$ & 73 & 173 & 100 & 173 & 130 & 125 & 100 & 182 & 135 & 135 & 130 \\
\hline
\end{tabular}

Sumber: Peneliti, 2018 
Kala ulang yang dipakai adalah periode ulang hujan 10 tahun, berdasarkan tipologi kota metropolitan dan luas daerah pengaliran antara $100 \mathrm{Ha}$ sampai $500 \mathrm{Ha}$. Peta DAS dan Catchment Area Sungai Tlogosari, dapat dilihat pada Gambar 2.

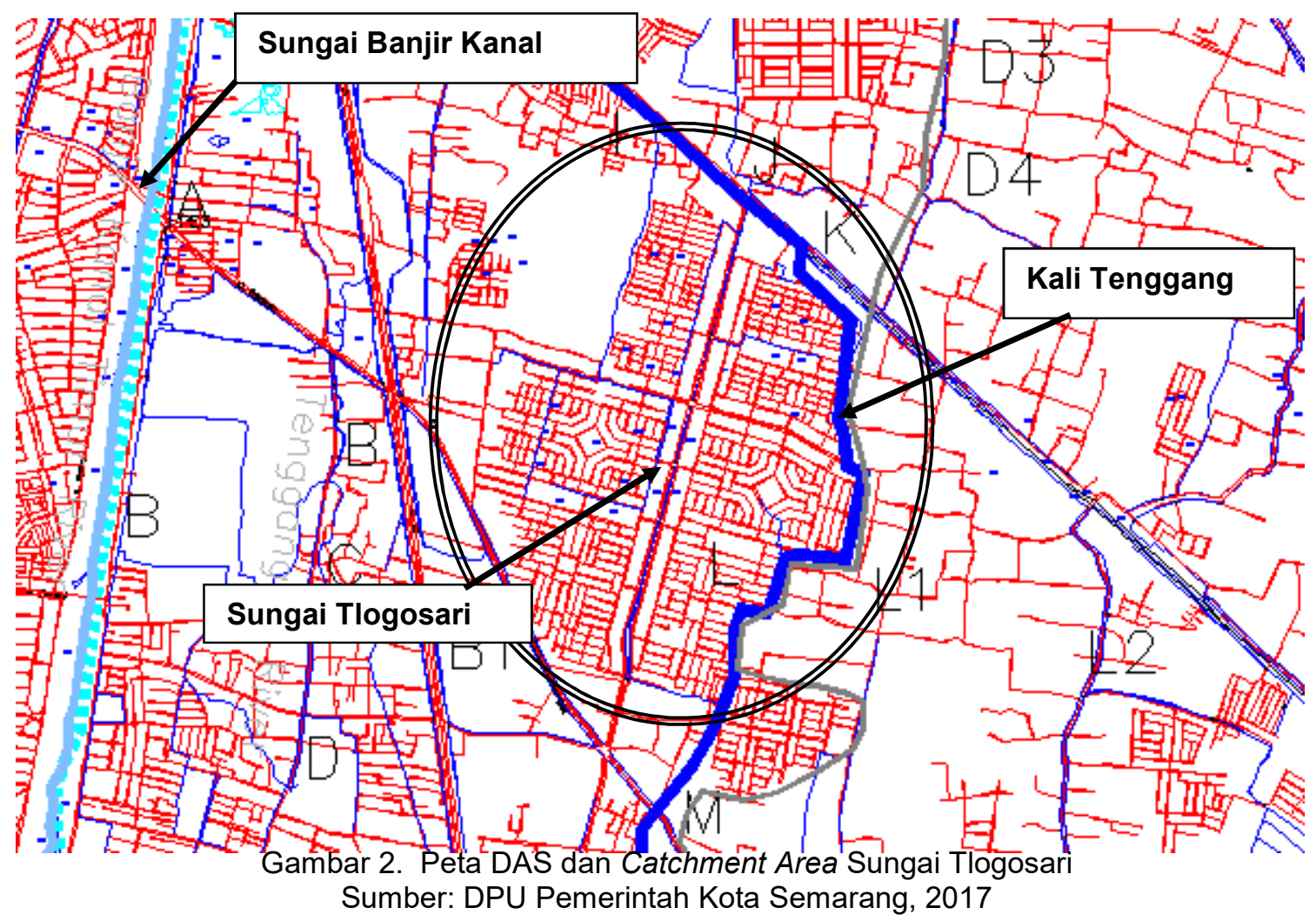

Dari Gambar 2 di atas tampak bahwa Sungai Tlogosari merupakan bagian sub sistem Kali Tenggang sehingga Sungai Tlogosari bermuara ke Kali Tenggang

Hujan rencana dihitung dengan teori probability distribution, yaitu dipilih Distribusi Gumbel dan Distribusi Log Pearson type III. Parameter statistik yang digunakan meliputi nilai rata-rata $(\overline{\mathrm{X}})$, simpangan baku (Sd), koefisien variasi $(\mathrm{Cv})$, koefisien kemiringan (Cs), dan koefisien kurtosis (Ck). Berikut ini adalah perhitungan parameter statistik dengan Metode Gumbel dan Metode Log Pearson type III. Perhitungan hujan rencana tertera pada Tabel 2.

Tabel 2. Perhitungan Parameter Statistik

\begin{tabular}{llll}
\hline & Gumbel Tipe I & \multicolumn{1}{c}{ Log Pearson Tipe III } \\
\hline $\mathrm{n}$ & 11 & $\mathrm{n}$ & 11 \\
Jumlah & 1507 & Jumlah Log & 23,42 \\
Xrt & 137,00 & Log Xrt & 2,13 \\
$\mathrm{~S}(\mathrm{X}-\mathrm{Xrt})^{\wedge} 2$ & 7774,00 & $\mathrm{~S}($ Log X-LogXrt)^2 & 0,077 \\
$\mathrm{~S}(\mathrm{X}-\mathrm{Xrt})^{\wedge} 3$ & 78504,00 & $\mathrm{~S}($ LogX-LogXrt) & 0,001 \\
$\mathrm{SX}$ & 27,882 & $\mathrm{~S}$ Log X & 0,088 \\
Yn (tabel) & 0,4996 & $\mathrm{Cs}$ & 0,099 \\
Sn (tabel) & 0,9676 & Ck & $-0,656$ \\
\hline
\end{tabular}

Sumber : Hasil Perhitungan Peneliti, 2018

Dari Tabel 2 tersebut, hasil perhitungan dapat diurikan sebagai berikut:

1. Perhitungan metode Gumbell: $C s=0,44$ dekat dengan syarat Gumbell 1,14

2. $\mathrm{Ck}=-0,75$ jauh dengan syarat Gumbell 5,4 
3. Perhitungan metode Log Pearson type III

4. Cs $=0,10$ memenuhi syarat Log Pearson type III Ck $>0$

5. $C k=-0,66$ cukup dekat dengan syarat Log Pearson type III

Dari hasil uraian tersebut, maka dipilih Distribusi Log Pearson type III, sehingga hujan rencana periode $\mathrm{T}$ tahun apat dilihat pada Tabel 3.

Tabel 3. Hujan Rencana Periode T tahun

\begin{tabular}{cccc}
\hline $\mathrm{T}$ (thn) & $\mathrm{k}$ & $\log \mathrm{XT}(\mathrm{mm})$ & $\mathrm{XT}(\mathrm{mm})$ \\
\hline 2 & $-0,017$ & 2,127 & 134,02 \\
5 & 0,836 & 2,202 & 159,22 \\
10 & 1,292 & 2,242 & 174,58 \\
25 & 1,785 & 2,285 & 192,86 \\
\hline
\end{tabular}

Sumber : Hasil Perhitungan Peneliti, 2018

Debit banjir rencana dihitung dengan Metode Rasional (Hindarko, 2000), karena DAS nya yang lebih kecil dari $500 \mathrm{Ha}$. Selanjutnya dihitung Waktu Konsentrasi (tc) yaitu waktu yang dibutuhkan oleh limpasan untuk melalui jarak terjauh di daerah tadah hujan yaitu di suatu titik di hulu sampai ke titik tinjau paling akhir, Intensitas Hujan dengan hujan rencana sesuai dengan kala ulang banjirnya, dan Koefisien Limpasan (C) berdasarkan faktor iklim dan fisiografi, seperti rumus berikut ini:

Tc

$$
\begin{aligned}
& =0,0195^{\star}\left(L^{0,77}\right)^{\star}\left(S^{-0,385}\right) \\
& =0,0195^{\star}\left(1.746^{0,77}\right)^{\star}\left(0,000837^{\wedge-0,385}\right) \\
& =93,58 \text { menit } \\
& =\operatorname{Rt} / 24 \times(24 /(T c / 60))^{2 / 3}
\end{aligned}
$$

Keterangan :

Rt $\quad=$ Hujan Rencana pada kala ulang tertentu

(dari perhitungan hujan rancangan Log Pearson type III)

C $\quad=\mathrm{Ci}+\mathrm{Ct}+\mathrm{Cp}+\mathrm{Cs}+\mathrm{Cc}=0,7$

Keterangan :

$$
\begin{array}{ll}
\mathrm{Ci} & =0,15 \text { (intensitas hujan bervariasi antara } 25-50 \mathrm{~mm} / \mathrm{jam} \text { ) } \\
\mathrm{Ct} & =0,05 \text { (kondisi topografi landai) } \\
\mathrm{Cp} & =0,05 \text { (tampungan daerah pengaliran dengan sistem teratur) } \\
\mathrm{Cs} & =0,2 \text { (infiltrasi lambat) } \\
\mathrm{Cc} & =0,25 \text { (tidak ada tumbuhan penutup lahan) }
\end{array}
$$

Kemudian dihitung Debit Banjir Rencana dengan rumus :

$$
Q=0.278 \times C \times I \times A
$$

Hasil perhitungan debit banjir rencana dapat dilihat pada Tabel 4.

Tabel 4. Perhitungan Debit Banjir Rencana

\begin{tabular}{ccccc}
\hline No. & $\mathbf{R t}(\mathbf{m m})$ & $\mathbf{I}(\mathbf{m m} / \mathbf{j a m})$ & $\begin{array}{c}\mathbf{Q} \\
\left(\mathbf{m}^{3} / \mathbf{d e t}\right)\end{array}$ & $\mathbf{T}$ \\
\hline 1 & 134,02 & 34,54 & 11,70 & 2 \\
\hline 2 & 159,22 & 41,04 & 13,90 & 5 \\
\hline 3 & 174,58 & 45,00 & 15,24 & 10 \\
\hline 4 & 192,86 & 49,71 & 16,83 & 20 \\
\hline \multicolumn{5}{c}{ Sumber : Hasil Perhitungan Peneliti, 2018 }
\end{tabular}

\section{Analisis Kapasitas Tampung Sungai Tlogosari}

Analisis kapasitas dilakaukan dengan membandingkan kapasitas tampung Sungai Tlogosari dengan kapasitas tampung sesuai dengan debit banjir rencana kala ulang 10 
tahun. Berdasarkan survei lapangan terjadi sedimentasi sepanjang saluran rata-rata $20 \mathrm{~cm}$, dan dengan debit rencana $>15 \mathrm{~m} 3 /$ detik, disyaratkan menggunakan tinggi jagaan $1 \mathrm{~m}$, maka tinggi saluran basah adalah $3 \mathrm{~m}-1 \mathrm{~m}-0,2 \mathrm{~m}=1,8 \mathrm{~m}$, sehingga :

1. Keliling penampang basah $(O)=9,22 \mathrm{~m}$

2. Luas penampang sungai $(A)=10,98 \mathrm{~m}^{2}$

3. Jari-jari hidrolis $(\mathrm{R})$

4. Kecepatan aliran (V)

$=1,19 \mathrm{~m}$

$=1,30 \mathrm{~m} /$ detik

Kapasitas tampung saluran dihitung dengan pendekatan rumus kontinuitas $=14,30$ $\mathrm{m}^{3} /$ detik.

Dari perhitungan di atas didapat hasil bahwa kapasitas tampung Sungai Tlogosari $\left(14,30 \mathrm{~m}^{3} /\right.$ detik) lebih kecil dari debit rencananya (15,24 $\mathrm{m}^{3} /$ detik). Dengan menggunakan dimensi sungai Tlogosari tinggi saluran basah rencana adalah $1,87 \mathrm{~m}$. Terdapat selisih kekurangan tinggi $0,07 \mathrm{~m}$. Dengan tinggi jagaan $1 \mathrm{~m}$, seharusnya pada curah hujan normal Sungai Tlogosari tidak meluap. Berdasarkan perhitungan kapasitas tampung saluran yang menunjukkan bahwa dengan adanya tinggi jagaan maka Sungai Tlogosari masih mampu menampung $\mathrm{p}$ debit yang masuk Hambatan ini tentu menambah waktu konsentrasi sehingga akan menambah debit yang masuk (waktu konsentrasi Sungai Tlogosari eksisting pada musim hujan tidak dihitung karena penelitian dilakukan pada musim kemarau)

Jadi dari perbandingan dengan kapasitas rencana kapasitas tampung Sungai Tlogosari, walaupun debit rencana lebih besar, kapasitas tamping Sungai Tlogosari masih mencukupi karena adanya tinggi jagaan $(1 \mathrm{~m})$ yang lebih besar dari selisih kekurangan tinggi jagaan rencana $(0,07 \mathrm{~m})$. Maka jika Sungai Tlogosari masih meluap itu disebabkan faktor lain, antara lain karena banyaknya sedimen dan sampah di sepanjang saluran dan karena Sungai Tlogosari adalah sub system Drainase Kali Tenggang yang belum selesai dinormalisasi, sehingga jika hujan aliran Sungai Tlogosari akan terhambat. ketika akan memasuki drainase primernya.

\section{Analisis Kapasitas Tampung Saluran Tersier.}

Perhitungan kapasitas tampung saluran sekunder, yaitu saluran yang masuk ke Sungai Tlogosari prinsipnya sama dengan perhitungan kapasitas tampung Sungai Tlogosari, selanjutnya diadakan penyesuaian untuk kala ulang, luas area tangkapan, luas penampang saluran, dan kemiringan.

Pemberian nama saluran tersier disusun dengan menyesuaikan pada pembagian kawasan berdasarkan wilayah administrasi dan kawasan timur dan barat Sungai Tlogosari, sebagaimana ditunjukkan Tabel 5 berikut ini.

Tabel 5. Nama Saluran Sekunder

\begin{tabular}{lllrrrr}
\hline No. & $\begin{array}{l}\text { Nama } \\
\text { Saluran }\end{array}$ & Posisi & $\begin{array}{r}\text { Luas } \\
\left(\mathrm{km}^{2}\right)\end{array}$ & $\begin{array}{c}\text { Panjang } \\
(\mathrm{m})\end{array}$ & $\begin{array}{c}\text { Elevasi } \\
\text { Hulu }\end{array}$ & $\begin{array}{c}\text { Elevasi } \\
\text { Hilir }\end{array}$ \\
\hline $\mathbf{1}$ & Sekunder 1 & Jl. Tlogo Timun & 0,0663 & 355 & 6,63 & 6,21 \\
\hline $\mathbf{2}$ & Sekunder 2 & JI. Parang Kembang & 0,0552 & 425 & 6,50 & 6,09 \\
\hline $\mathbf{3}$ & Sekunder 3 & JI Parang Klitik & 0,0945 & 435 & 6,39 & 5,96 \\
\hline $\mathbf{4}$ & Sekunder 4 & Jl Taman Udan Riris (utara) & 0,0809 & 390 & 6,29 & 5,84 \\
\hline $\mathbf{5}$ & Sekunder 5 & JI Taman Udan Riris (selatan) & 0,0794 & 490 & 6,16 & 5,71 \\
\hline $\mathbf{6}$ & Sekunder 6 & JI. Parang Baris (utara) & 0,0639 & 580 & 6,07 & 5,59 \\
\hline $\mathbf{7}$ & Sekunder 7 & JI.Parang Sapo (selatan) & 0,0609 & 580 & 5,87 & 5,46 \\
\hline $\mathbf{8}$ & Sekunder 8 & JI. Nogososro (selatan) & 0,0699 & 610 & 5,79 & 5,34 \\
\hline $\mathbf{9}$ & Sekunder 9 & JI Parang Kusumo 1 & 0,0753 & 310 & 5,79 & 5,34 \\
\hline $\mathbf{1 0}$ & Sekunder 10 & JI Gusti Putri & 0,0811 & 440 & 6,52 & 6,11 \\
\hline $\mathbf{1 1}$ & Sekunder 11 & JI Satria Wibowo 3 (selatan) & 0,0911 & 505 & 6,46 & 5,98 \\
\hline $\mathbf{1 2}$ & Sekunder 12 & JI Satria Wibowo 3 (utara) & 0,1378 & 505 & 6,30 & 5,85 \\
\hline
\end{tabular}




\begin{tabular}{lllllll}
\hline $\mathbf{1 3}$ & Sekunder 13 & JI Parang Barong & 0,0895 & 540 & 6,14 & 5,72 \\
\hline $\mathbf{1 4}$ & Sekunder 14 & JI Truntum & 0,0779 & 540 & 6,06 & 5,59 \\
\hline $\mathbf{1 5}$ & Sekunder 15 & JI. Gajah Birowo (selatan) & 0,0864 & 590 & 5,91 & 5,46 \\
\hline $\mathbf{1 6}$ & Sekunder 16 & JI Nogososro (utara) & 0,0759 & 610 & 5,81 & 5,33 \\
\hline $\mathbf{1 7}$ & Sekunder 17 & JI Taman Suryo Kusumo (utara) & 0,0644 & 410 & 5,50 & 5,05 \\
\hline $\mathbf{1 8}$ & Sekunder 18 & JI Taman Suryo Kusumo (selatan) & 0,0745 & 410 & 5,18 & 4,77 \\
\hline $\mathbf{1 9}$ & Sekunder 19 & JI Sidodrajat (ujung utara) & 0,0591 & 340 & 4,92 & 4,49 \\
\hline $\mathbf{2 0}$ & Sekunder 20 & JI Gajah Birowo (utara) & 0,0551 & 315 & 5,82 & 5,46 \\
\hline $\mathbf{2 1}$ & Sekunder 21 & JI Tejo Kusumo (utara) & 0,0418 & 310 & 5,56 & 5,18 \\
\hline $\mathbf{2 2}$ & Sekunder 22 & JI Tejo Kusumo (selatan) & 0,0492 & 310 & 5,25 & 4,90 \\
\hline $\mathbf{2 3}$ & Sekunder 23 & JI Sido Asih & 0,1132 & 325 & 5,01 & 4,62 \\
\hline & Sumber : Hasil Perhitungan Peneliti, 2018 & & &
\end{tabular}

Kemudian dihitung debit rencana masing-masing saluran sekunder menggunakan debit rencana kala ulang 2 tahun karena luas DAS masing-masing saluran sekunder kurang dari 2 HA. Berikut ini perhitungan debit rencana masing-masing saluran sekunder, dengan penyesuaian pada luas DAS, dimensi saluran, elevasi hulu dan hilir, hujan rencana kala ulang 2 tahun, waktu konsentrasi dan intensitas hujan pada masing-masing saluran tersier, sebagaimana ditunjukkan Tabel 6 berikut ini:

Tabel 6. Perhitungan Debit Rencana Saluran Sekunder Sungai Tlogosari

\begin{tabular}{clrrrrc}
\hline NO. & Nama Saluran & $\mathbf{S}$ & $\mathrm{R} 2$ & $\mathrm{Tc}$ & $\mathrm{I}$ & $\mathrm{Q}(\mathbf{2 T h})$ \\
\cline { 3 - 6 } & & $\mathbf{m} / \mathbf{m}$ & $\mathbf{m m}$ & $\mathbf{m e n i t}$ & $\mathbf{m m} / \mathbf{j a m}$ & $\mathbf{m}^{\mathbf{3} / \mathbf{d e t}}$ \\
\hline $\mathbf{1}$ & Sekunder 1 & 0,0012 & 134,02 & 24,02 & 41,12 & 0,53 \\
\hline $\mathbf{2}$ & Sekunder 2 & 0,0010 & 134,02 & 29,85 & 35,58 & 0,38 \\
\hline $\mathbf{3}$ & Sekunder 3 & 0,0010 & 134,02 & 30,10 & 35,38 & 0,65 \\
\hline $\mathbf{4}$ & Sekunder 4 & 0,0012 & 134,02 & 26,08 & 38,93 & 0,61 \\
\hline $\mathbf{5}$ & Sekunder 5 & 0,0009 & 134,02 & 33,94 & 32,66 & 0,50 \\
\hline $\mathbf{6}$ & Sekunder 6 & 0,0008 & 134,02 & 40,23 & 29,16 & 0,36 \\
\hline $\mathbf{7}$ & Sekunder 7 & 0,0007 & 134,02 & 42,74 & 28,00 & 0,33 \\
\hline $\mathbf{8}$ & Sekunder 8 & 0,0007 & 134,02 & 43,71 & 27,59 & 0,38 \\
\hline $\mathbf{9}$ & Sekunder 9 & 0,0015 & 134,02 & 20,00 & 46,46 & 0,68 \\
\hline $\mathbf{1 0}$ & Sekunder 10 & 0,0009 & 134,02 & 31,07 & 34,64 & 0,55 \\
\hline $\mathbf{1 1}$ & Sekunder 11 & 0,0010 & 134,02 & 34,28 & 32,44 & 0,58 \\
\hline $\mathbf{1 2}$ & Sekunder 12 & 0,0009 & 134,02 & 35,14 & 20,10 & 0,54 \\
\hline $\mathbf{1 3}$ & Sekunder 13 & 0,0008 & 134,02 & 38,99 & 29,77 & 0,52 \\
\hline $\mathbf{1 4}$ & Sekunder 14 & 0,0009 & 134,02 & 37,34 & 30,64 & 0,46 \\
\hline $\mathbf{1 5}$ & Sekunder 15 & 0,0008 & 134,02 & 42,06 & 28,31 & 0,48 \\
\hline $\mathbf{1 6}$ & Sekunder 16 & 0,0008 & 134,02 & 42,64 & 28,05 & 0,41 \\
\hline $\mathbf{1 7}$ & Sekunder 17 & 0,0011 & 134,02 & 27,63 & 37,46 & 0,47 \\
\hline $\mathbf{1 8}$ & Sekunder 18 & 0,0010 & 134,02 & 28,63 & 36,58 & 0,53 \\
\hline $\mathbf{1 9}$ & Sekunder 19 & 0,0013 & 134,02 & 22,65 & 42,77 & 0,49 \\
\hline $\mathbf{2 0}$ & Sekunder 20 & 0,0011 & 134,02 & 22,20 & 43,34 & 0,46 \\
\hline $\mathbf{2 1}$ & Sekunder 21 & 0,0012 & 134,02 & 21,35 & 44,49 & 0,36 \\
\hline $\mathbf{2 2}$ & Sekunder 22 & 0,0011 & 134,02 & 22,03 & 43,56 & 0,42 \\
\hline & & & & & &
\end{tabular}


Keterangan Tabel 6 tersebut adalah sebagai berikut :

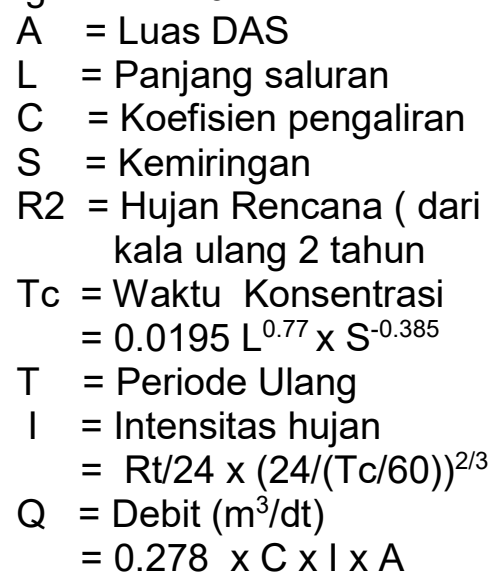

Kemudian dilakukan perhitungan kapasitas tampung masing-masing saluran sekunder dengan menggunakan tinggi jagaan $0,2 \mathrm{~m}$, karena debit hujan kurang dari 1 m3/detik. Hasilnya dibandingkan dengan kapasitas saluran Sekunder masing-masing, apakah lebih besar atau lebih kecil. Juga dilakukan perhitungan kapasitas tampung saluran Sekunder dengan meniadakan tinggi jagaan untuk mengetahui apakah terjadi luapan air apabila kapasitas tampung lebih kecil dari debit rencana. Hasil perhitungan kapasitas tampung saluran sekundervsungai Tlogosari tertera pada Tabel 7.

Tabel 7 Perhitungan Kapasitas Tampung Saluran Sekunder Sungai Tlogosari

\begin{tabular}{|c|c|c|c|c|c|c|c|c|c|}
\hline \multirow[t]{3}{*}{ No. } & \multirow[t]{3}{*}{ Ruas } & \multirow{2}{*}{$\begin{array}{c}\text { Panjang } \\
\mathrm{L}\end{array}$} & \multicolumn{5}{|c|}{ Eksisting } & \multirow{2}{*}{$\begin{array}{l}\text { Rencana } \\
\text { Q Desain }\end{array}$} & \multirow[t]{3}{*}{ Keterangan } \\
\hline & & & A & $\mathrm{R}$ & $S$ & V & $\begin{array}{c}\mathrm{Q} \\
\text { Saluran }\end{array}$ & & \\
\hline & & (m) & $\left(m^{2}\right)$ & (m) & & $(\mathrm{m} / \mathrm{dt})$ & $\left(\mathrm{m}^{3} / \mathrm{dt}\right)$ & $\left(m^{3} / d t\right)$ & \\
\hline 1 & Sekunder 1 & 355 & 0,50 & 0,25 & 0,00118 & 0,68 & 0,34 & 0,53 & Rawan \\
\hline 2 & Sekunder 2 & 425 & 0,40 & 0,22 & 0,00096 & 0,57 & 0,23 & 0,38 & Rawan \\
\hline 3 & Sekunder 3 & 435 & 0,66 & 0,29 & 0,00099 & 0,68 & 0,45 & 0,65 & Rawan \\
\hline 4 & Sekunder 4 & 390 & 0,66 & 0,29 & 0,00115 & 0,74 & 0,49 & 0,61 & Aman \\
\hline 5 & Sekunder 5 & 490 & 0,66 & 0,29 & 0,00092 & 0,66 & 0,44 & 0,50 & Aman \\
\hline 6 & Sekunder 6 & 580 & 0,66 & 0,29 & 0,00083 & 0,63 & 0,41 & 0,36 & Aman \\
\hline 7 & Sekunder 7 & 580 & 0,60 & 0,27 & 0,00071 & 0,56 & 0,34 & 0,33 & Aman \\
\hline 8 & Sekunder 8 & 610 & 0,66 & 0,29 & 0,00074 & 0,59 & 0,39 & 0,38 & Aman \\
\hline 9 & Sekunder 9 & 310 & 0,60 & 0,27 & 0,00145 & 0,80 & 0,48 & 0,68 & Rawan \\
\hline 10 & Sekunder 10 & 440 & 0,60 & 0,27 & 0,00093 & 0,64 & 0,39 & 0,55 & Rawan \\
\hline 11 & Sekunder 11 & 505 & 0,60 & 0,27 & 0,00095 & 0,65 & 0,39 & 0,58 & Meluap \\
\hline 12 & Sekunder 12 & 505 & 0,60 & 0,27 & 0,00089 & 0,63 & 0,38 & 0,54 & Rawan \\
\hline 13 & Sekunder 13 & 540 & 0,60 & 0,27 & 0,00078 & 0,59 & 0,35 & 0,52 & Meluap \\
\hline 14 & Sekunder 14 & 540 & 0,60 & 0,27 & 0,00087 & 0,62 & 0,37 & 0,46 & Aman \\
\hline 15 & Sekunder 15 & 590 & 0,66 & 0,29 & 0,00076 & 0,60 & 0,40 & 0,48 & Aman \\
\hline 16 & Sekunder 16 & 610 & 0,66 & 0,29 & 0,00079 & 0,61 & 0,40 & 0,41 & Aman \\
\hline 17 & Sekunder 17 & 410 & 0,60 & 0,27 & 0,00110 & 0,70 & 0,42 & 0,47 & Aman \\
\hline 18 & Sekunder 18 & 410 & 0,60 & 0,27 & 0,00100 & 0,66 & 0,40 & 0,53 & Rawan \\
\hline 19 & Sekunder 19 & 340 & 0,50 & 0,25 & 0,00126 & 0,71 & 0,35 & 0,49 & Aman \\
\hline 20 & Sekunder 20 & 315 & 0,50 & 0,25 & 0,00114 & 0,67 & 0,34 & 0,46 & Aman \\
\hline
\end{tabular}




\begin{tabular}{llllllllll}
\hline $\mathbf{2 1}$ & Sekunder 21 & 310 & 0,50 & 0,25 & 0,00123 & 0,69 & 0,35 & 0,36 & Aman \\
\hline $\mathbf{2 2}$ & Sekunder 22 & 310 & 0,50 & 0,25 & 0,00113 & 0,67 & 0,33 & 0,42 & Aman \\
\hline $\mathbf{2 3}$ & Sekunder 23 & 325 & 0,50 & 0,25 & 0,00120 & 0,69 & 0,34 & 0,60 & Meluap \\
\hline
\end{tabular}

Sumber : Hasil Perhitungan Peneliti, 2018

Dari Tabel 7 Perhitungan Kapasitas Tampung Saluran Sekunder Saluran Drainase Sungai Tlogosari tampak bahwa hanya 13 (tiga belas) saluran Sekunder yaitu saluran Sekunder 4, 5, 6, 7, 8, 14, 15, 16, 17, 19, 20, 21, 22 yang tidak meluap jika terjadi banjir kala ulang 2 tahun, 7 (tujuh) saluran Sekunder yaitu saluran Sekunder 1, 2, 3, 9, 10, 11, 12, 13, 14 rawan artinya tinggi kapasitas sama (atau hampir sama) dengan tinggi debit rencananya dan 3 (tiga) saluran yaitu saluran Sekunder 11, 13, 23 meluap jika terjadi banjir kala ulang 2 tahun.

Maka dapat dikatakan kinerja saluran-saluran sekunder berkategori buruk karena kapasitas tampungnya lebih kecil dari debit rencana. Maka selain membersihkan sedimen dan sampah yang banyak terdapat pada saluran, dimensi saluran harus dibesarkan yaitu dengan menambah kedalaman saluran.

\section{KESIMPULAN}

Kapasitas tampung Sungai Tlogosari sudah mencukupi. Walaupun debit banjirnya $\left(14,30 \mathrm{~m}^{3} /\right.$ detik) lebih kecil dari debit rencananya $\left(15,24 \mathrm{~m}^{3} /\right.$ detik), tetapi dengan kekurangan tinggi basah saluran hanya 0,07 meter dapat teratasi dengan tinggi jagaan 1 meter. Kalau saluran ini meluap pada musim hujan itu disebabkan oleh sampah dan sedimen, juga karena Sungai Tlogosari merupakan sub sistem dari Drainase Kali Tenggang belum dinormalisasi (Agung, 2014), sehingga aliran Sungai Tlogosari terhambat. Pada saluran-saluran sekunder, sebagian besar kapasitas tampungnya lebih kecil dari debit rencananya. Kapasitas saluran-saluan sekunder pada range $0,23 \mathrm{~m}^{3} /$ detik sampai dengan $0,49 \mathrm{~m}^{3} /$ detik, sedangkan debit rencana saluran-saluran tersebut pada range $0,33 \mathrm{~m}^{3} / \mathrm{detik}$ sampai dengan $0,68 \mathrm{~m}^{3} /$ detik. Hanya 13 saluran sekunder dari total 23 saluran sekunder yang kapasitas tampungnya lebih besar dari debit rencananya, sisanya cenderung meluap. Maka berdasarkan kapasitas tampungnya kapasitas tampung Sungai Tlogosari cukup baik, sedangkan saluran-saluran sekundernya kurang baik. Kapasitas tampung saluran sekunder harus diperbesar yaitu dengan menambah kedalaman saluran. Sebagai sub sistem dari Sistem Drainase Kali Tenggang perlu diteliti pengaruh belum selesainya normalisasi Kali Tenggang terhadap hambatan aliran Sungai Tlogosari.

\section{DAFTAR PUSTAKA}

Agung, Martin, Martunas. 2014. Perencanaan Sistem Drainase Kali Tenggang . Jurnal Karya Teknik Sipil, Volume 3, Nomor 1.

Danianti, P., dan Sariffuddin, Rizsa. 2015. Tingkat Kerentanan Masyarakat Terhadap Bencana Banjir Di Perumnas Tlogosari, Kota Semarang. Jurnal Pengembangan Kota

Dewi, K., Ajeng., dan Setiawan, A., dan Saido, A. 2014. Evaluasi Sistem Saluran Drainase Di Ruas Jalan Solo Sragen Kabupaten Karanganyar. Matriks Teknik Sipil Vol. 2 No. 1/Maret 2014.

Hindarko, S.2010. Drainase Perkotaan (Seri Lingkungan Hidup). Penerbit Andi, Yogyakarta.

Suryanti, I. 2013. Kinerja Sistem Jaringan Drainase Kota Semarapura Di Kabupaten Klungkung. Jurnal Spektran Vol. 1. No. 1, Januari 2013 Volume 3 No. 2015.

Wesly. 2008. Drainase Perkotaan. Graha IImu Yogyakarta 